\title{
IMPROVISATIONAL MODEL OF BUSINESS REGISTRATION FOR BRANDING SER VICES IN CONGO-BRAZZAVILLE
}

\author{
Alain Michael $\mathrm{MOMO}^{1}$
}

\author{
Received Date (Başvuru Tarihi): 04/05/2017 \\ Accepted Date (Kabul Tarihi): 16/05/2017 \\ Published Date (Yayın Tarihi): 03/06/2017
}

\begin{abstract}
Protracted Congo brand name's inability to attract investors spells ruin. The research problem is that despite the potential role that can play Information Systems (IS) improvisation in service branding in developing countries, Department of Trade and Industry (DTI) of Congo-Brazzaville does not have a normative model for online business registration. Such insufficiency stunts Congo's brand name as investment destination. The study purpose is to propose a normative model of online business registration for service branding. The study was conducted at the DTI Congo-Brazzaville using a mixed methodology. Findings reveal that $75 \%$ of respondents were male and $25 \%$ female. This variable leads to a conclusion that in the absence of normative model, the intention to adopt an online business registration system for re-branding DTI Congo is largely based on male employees' favourable attitudes towards e-commerce. $81.8 \%$ of respondents agreed that IS improvisation will close the gaps between the growing usage of e-commerce in the business world and the current total vacuum of it at DTI Congo. The major limitation is that the study does not recommend any specific e-commerce technology to DTI Congo, but as an institution, DTI Congo should evaluate the pros and cons of different e-commerce technologies, and then decide on the most appropriate one. In terms of originality, replacing brick-and-mortar business registration service by the online one at DTI Congo reflects a true contribution of this study to theories of brand personality, sustainability and green supply chain in a way far more impactful than recycling papers in the bin.
\end{abstract}

Keywords: Marketing, IS Improvisation, Nation Branding, DTI Congo-Brazzaville, Normative Model.

\section{KONGO-BRAZZAVILLE'DE MARKALAMA HIZMMETLERİ İÇIN TICARİ SİCIL DOĞAÇLAMA MODELİ}

ÖZ

Kongo marka adının uzun süredir yatırımcıları cezbedememesi yıkım anlamına gelmektedir. Araştırma problemi, gelişmekte olan ülkelerde markalama hizmetlerinin Bilgi Sistemlerinde (IS) oynayabileceği potansiyel role rağmen, Kongo-Brazzaville Ticaret ve Sanayi Bakanlı̆̆ının (DTI) çevrimiçi ticari sicil için normatif bir modelinin olmayışıdır. Böyle bir eksiklik Kongo marka adının bir yatırım bölgesi olarak gelişmesini engellemektedir. Bu çalışmanın amacı markalama hizmetlerinde çevrimiçi ticari sicil için normatif bir model önermektedir. Bu çalışma Kongo-Brazzaville Ticaret ve Sanayi Bakanlı̆̆ında karma yöntem kullanılarak yürütülmüşı̈̈r. Bulgular, katılımcıların 75\%'inin erkek, 25\%'inin kadın olduğunu ortaya koymuştur. Bu değişken normatif bir modelin yokluğunda, DTI Kongo'nun yeniden markalama için çevrimiçi ticari sicil sistemini

\footnotetext{
${ }^{1}$ Cape Peninsula University of Technology,Faculty of Business, Marketing Department, Cape Town-South Africa, momomike161@gmail.com
} 
benimseme niyetinin büyük ölçüde erkek çalışanların e-ticarete karşı olumlu tutumlarına dayandiğl sonucuna yol açmaktadır. Katılımcıların 81,8\%’i IS doğaçlamasının iş dünyasında e-ticaretin kullanılmasının artışı ve DTI Kongo 'daki mevcut total boşluk arasındaki açıkları kapatacağı konusunda hem fikirolmuşlardır. Bu çalışmanın ana kısıtlaması DTI Kongo için herhangi bir özel e-ticaret teknolojisi önerisinde bulunmamasıdır. Ancak bir kurum olarak DTI Kongo, farklı e-ticaret teknolojilerinin avantaj ve dezavantajlarını değerlendirmeli ve daha sonra en uygun olana karar vermelidir. Özgünlük açısından, DTI Kongo 'daki geleneksel ticari sicil hizmetlerinin çevrimiçi hizmetlerle değiştirilmesi, bu çalışmanın marka kişiliği, sürdürülebilirliği ve çevreci tedarik zinciri teorilere olan gerçek katkısını kâğıt geri dönüşümlerinin yapılmasından çok daha etkili bir biçimde yansıtacaktır.

Anahtar kelimeler: Pazarlama,, IS Doğaçlama, Ulusal Markalama,DTI Kongo-Brazzaville, NormatifModel. 


\section{INTRODUCTION}

The case study boundary includes the Ministère du Commerce et des approvisionnements, which refers to the DTI Congo-Brazzaville. The DTI Congo claims to be in the junctions of all economic activities of the country. It also oversees the promotion of ecommerce and SMEs' development nationwide (Ministère du Commerce, 2014). However, to lighten DTI Congo's duties, the Congolese government created the Centre for Business and Administrative Procedures (CFBAP): Centre de Formalités des Entreprises (CFE) under decree $\mathrm{n}^{\circ}$ 94-568 of 10 October, 1994 and modified it by the decree $\mathrm{n}^{\circ}$ 95-183 of 18 October, 1995 . Though DTI Congo-Brazzaville's mission includes promotion of business and e-commerce, its Website http://www.congo-info.com/minister/35 does not offer any e-commerce support to all stakeholders including suppliers, entrepreneurs, SMEs, and consumers. More than that, the Congo-Brazzaville's CFBAP is placed under joint authority of the DTI and the Ministry of Small and Medium-Sized Enterprises (SMEs) (Yétéla, 2012). Sadly, ground observation reveals that the Ministry of SMEs in Congo-Brazzaville does not have a dedicated Website either (Chambre de Commerce, d'Agriculture, d'Industry et de Métier de Brazzaville, 2014).

Hence, regardless of the CFBAP's efforts of simplifying the business registration process to less than an hour, Congo-Brazzaville is still ranked 185th out of 189 countries for the ease of doing business (Doing Business, 2014). Further, lack of economic diversification translates that 90 percent of the country's Gross Domestic Product (GDP) is from oil revenue and all the remaining sectors account for only 10 percent (Yétéla, 2012). Such disproportions amongst economic sectors show insufficient economic diversification in terms of SMEs' support, owing to the government's utter reliance on petroleum sector to generate income.

Practically, business registration services in Congo-Brazzaville are sub-devised into three sections. The first section is for new business registration, the second deals with modification of legal status of an existing business and the third is about cancelation and de-registration of business. In the first section of new business registration, which is the main interest of the study, required documents include the followings as indicated in Table I. 
Table I. Documents Required To Register Business in Congo-Brazzaville

\begin{tabular}{|l|c|c|}
\hline No & Natural person & Corporation \\
\hline 01 & Birth certificate or any identification document & 2 certified copies of corporate status \\
\hline 02 & Long stay Visa (for foreigners) & 2 copies of capital subscription declaration \\
\hline 03 & Marriage certificate (if applicable) & 2 copies of management team list \\
\hline 04 & Police clearance & 2 police clearances for each person in the list \\
\hline 05 & Permanent residence (if applicable) & Corporate name \\
\hline 06 & Banking details & Banking details \\
\hline 07 & Copy of lease agreement & Investment, job and environment strategy \\
\hline 08 & Act of acquisition (if applicable) & Provisional operating account for the 3 years \\
\hline 09 & 3 passport format pictures & Equipment strategy \\
\hline 10 & Business name (must differ from applicant's) & Lease agreement \\
\hline 11 & Business registration fees & 3 passport format pictures for each applicant \\
\hline 12 & & List subject to change based on business nature \\
\hline 13 & &
\end{tabular}

Entrepreneurs and small business owners are subjected to business registration fees. In Congo-Brazzaville, the Act $N^{\circ}$ 36-2011 of 29 December 2011 stipulates financial regulations of 2012 fixes business registration fees for nationals and foreigners. Section 8 of the Act $N^{\circ} 36$ 2011 of December 292011 stipulates that entrepreneurs and small business owners are subjected to a single tax payment included in business registration fees. The tax is collected by the CFBAP for the Congolese government, and after payment the CFBAP issues the applicant with a merchant's card, a business registration statement with registration number, a business accounting registration number, and a commerce registry and real estate credit number (Yétéla, 2012). However, Section 9 of the Act $N^{\circ}$ 36-2011 of December 292011 stipulates that entrepreneurs and small business owners are subjected to business fees as described in Table II.

Table II. Business Registration Fees Classification in Congo-Brazzaville

\begin{tabular}{|c|c|c|}
\hline No & Nature of transaction & Fees in \$USA \\
\hline 01 & Close Corporation (CC) & 200.00 \\
\hline 02 & Corporation (Pty) & 600.00 \\
\hline 03 & Capital Company (CC Pty) & $1,000.00$ \\
\hline 04 & De-registration or modification & 0.00 \\
\hline 05 & Non-EECAS business pay plus 1\% of minimum capital & $2,000.00$ \\
\hline 06 & Agricultural and marine transport business get 50 \% discount & Flexible \\
\hline
\end{tabular}

Arguably, paying relevant business registration fees at the CFBAP office is just one step within the process. Such fees only enable the registered business to have unique business numbers (Yétéla, 2012). A study conducted by PMC Cabinet (2006) about investment barriers in Congo-Brazzaville reveals that before being operational, entrepreneurs and small business owners whose businesses have unique numbers should comply with further requirements stipulated in Table III.

Turkish Journal of Marketing Vol.:1 Issue:2 Year: 2016 pp. 163-194 
Table III. Further Compliance After Business Registration

\begin{tabular}{|c|c|c|c|}
\hline No & Requirement & Where to apply for & Cost in \$USA \\
\hline \multirow{2}{*}{01} & \multirow{2}{*}{ Notary Business Rules } & \multirow{2}{*}{ Notary } & Pty: $\quad 750.00$ \\
\hline & & & CC Pty: $1,000.00$ \\
\hline 02 & Notary subscription deed & Notary & $2 \%$ of capital \\
\hline \multirow[b]{2}{*}{03} & \multirow[b]{2}{*}{ Business rules registration } & \multirow[b]{2}{*}{ Taxation office } & $\begin{array}{c}\text { Pty:3\% of capital }+1.00 \text { for } \\
\text { each page }\end{array}$ \\
\hline & & & $\begin{array}{c}\text { CC Pty: } 3 \% \text { of capital }+10.00 \\
\text { for each page }\end{array}$ \\
\hline 04 & Foreigner's Identification card & Immigration & 210.00 \\
\hline 05 & Classification in newspaper & Local newspaper & 100.00 \\
\hline \multirow{7}{*}{06} & \multirow{7}{*}{ Regulated activity permit } & Offices & Flexible \\
\hline & & Forest & $4,000.00$ \\
\hline & & Mines & $1,000.00$ \\
\hline & & Geology & $2,000.00$ \\
\hline & & Fishery & Flexible \\
\hline & & Construction & 405.00 \\
\hline & & Tourism & 90.00 \\
\hline 07 & Business start-up statement & Labour Department & Flexible \\
\hline \multirow{3}{*}{08} & \multirow{3}{*}{ Investment chart purchase } & \multirow{3}{*}{$\begin{array}{c}\text { National } \\
\text { Investment commission }\end{array}$} & General: $\quad 1,000.00$ \\
\hline & & & Special: $\quad 500.00$ \\
\hline & & & Abstracted: 200.00 \\
\hline 09 & Work permit & ONEMO & 205.00 \\
\hline 10 & Importation license & DTI & 0.00 \\
\hline
\end{tabular}

In some instances, entrepreneurs engaged in the business registration process do not know what the requirements are for a particular sector of the economy. For example, it is not known with precision how much one should pay at the CFBAP when applying for an agricultural and marine transport business registration. The CFBAP being a self-centred organisation, small business owners, entrepreneurs and SMMEs data are merely a control tool for the Congolese government. Kotler (2003: 349) argues that organisations such as the CFBAP that fail to develop new services, e.g. an online business registration system, are putting themselves at great risk of brand deficiency.

The study answers the calls for a normative model for online business registration, as a part of the marketing function aimed at branding the CFBAP. Distinguished and refereed academic literature have concluded that e-commerce adoption within the governmental agency can contribute to branding nation. A few examples are Chan and Al-Hawamdeh (2002), Papathanassiou, Arkoumani and Kardaras (2003), Nikoloyuk, Marche and McNiven, (2005), Cumming (2011), Danzig (2002), Simpson and Docherty (2004) and Kotler (2003). The problem is that despite the potential role that can play Information Systems (IS) improvisation in service branding in developing countries, Department of Trade and Industry (DTI) of Congo-Brazzaville does not have a normative model for online business registration. From the above, the constructs are summarised in Figure 1. 


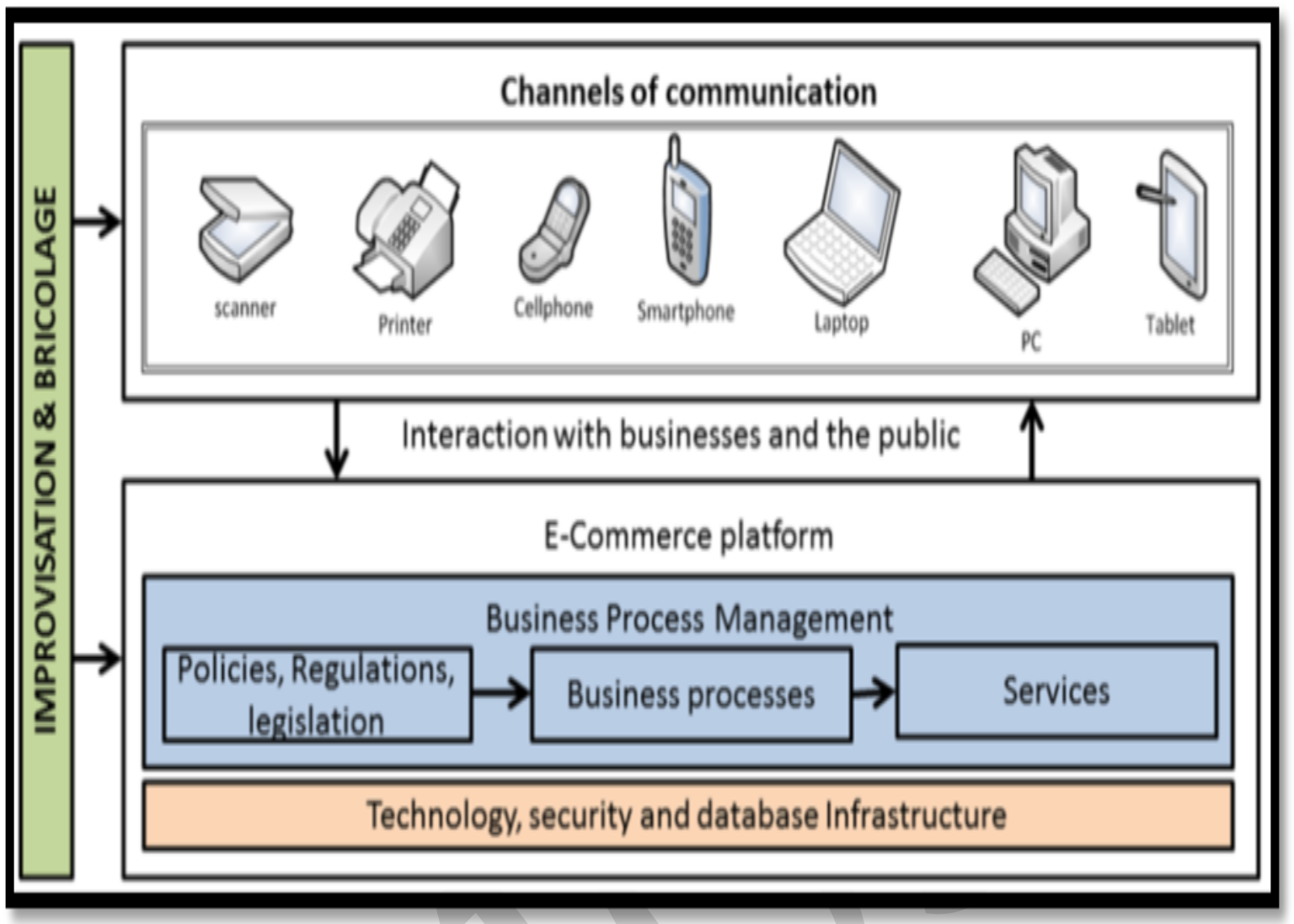

Figure 1. Problem Conceptualisation of IS Improvisation For Service Branding

Further discourse on how such innovation is expected to transform the organisation into a market-driven and its potential to re-brand the country as investment destination is discussed next.

2. OVERLAPS OF E-COMMERCE, BRICOLAGE AND IMPROVISATIONAL BRANDING

Given the usefulness of IS in service branding, attention has turned to the junctions of ecommerce, bricolage and improvisation. From branding perspectives, it becomes imperative to demarcate the overlaps of e-commerce, bricolage, and improvisation in the organisation (Baker, Miner \& Eesley, 2003). Figure 2 illustrates conceptual inter-relations. In the process of ecommerce new product development, IS improvisation may involve bricolage, however, bricolage in the organisation would occur when e-commerce planning precedes execution (Dybå, 2000). 


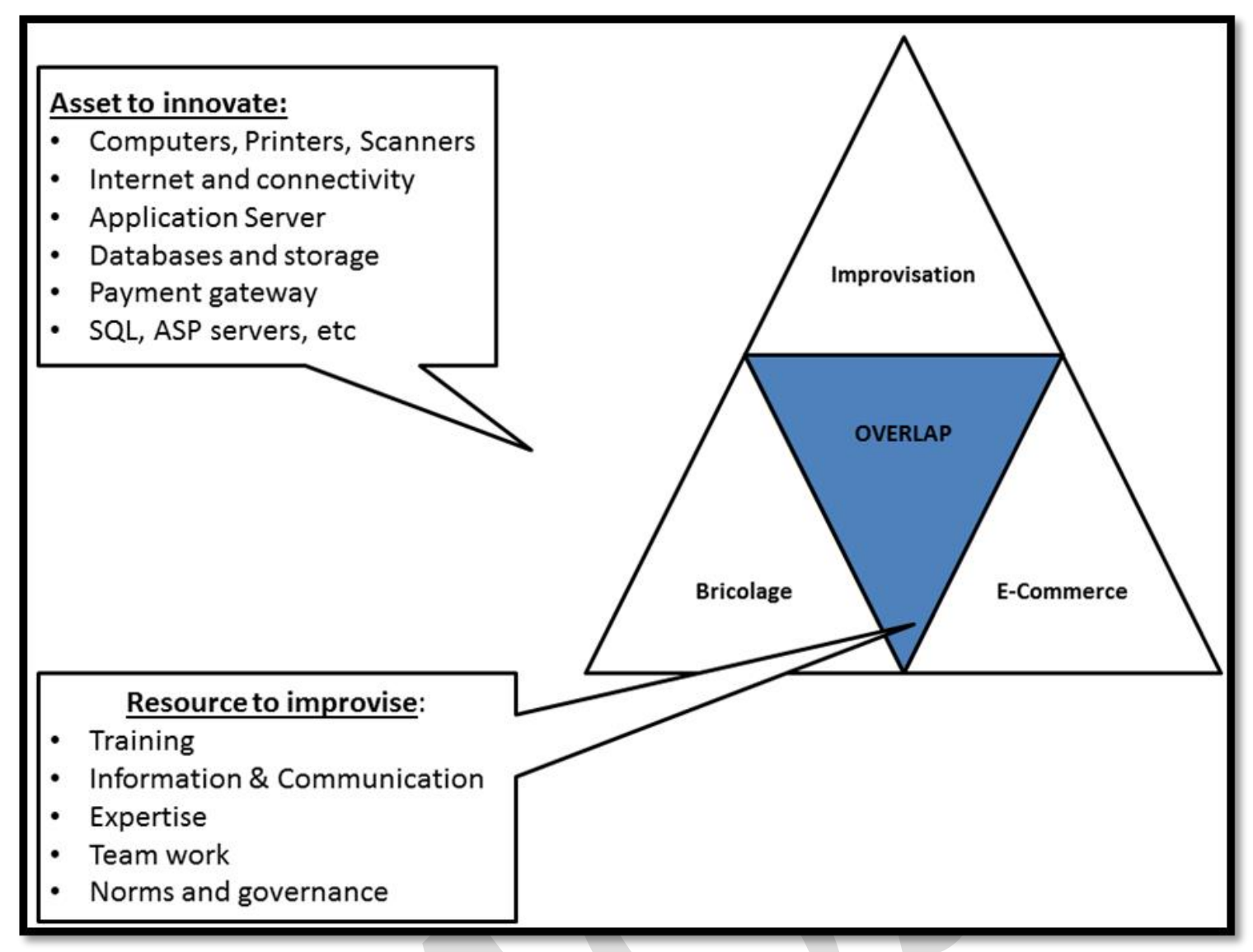

Figure 2. Overlaps of E-Commerce, Bricolage And Improvisation

The social phenomena under study is based on the awareness from Jazz and theatre improvisation. Even though many musicians from Wemba to Olomide of Congo emerged from improvisation on the stage (Congo Vision, 2015); it is arguable that IS improvisation is not to be assumed to be automatically associated with innovation and performance (Radio France International, 2015). Should there be, such direct transposition may rely heavily on descriptions of improvisation, which is termed as improvisation metaphor, and might not yield desired results (Chelariu, Johnston\& Young, 2002). Arguably, IS improvisation alone does not necessarily rebrand the organisation as innovative. However, there are five managerial dimensions to consider for the effectiveness of improvisation (Thomson \& Pian, 2003:79).

Faraj and Sproul (2000) argue that expertise, which encompasses specialised skills and knowledge that team members bring to the team work is the first dimension. Similarly, Amabile (1996) posits that field-relevance and job-related critical skill rely on team members' reasoning, perception, experience and education. Using musical concert as an example to explain team expertise, experienced musicians like Wemba and Olomide on the stage create a perception that improvisation is easy owing to the fact that they dedicate long hours of rehearsal before performing (Vukasovic, 2013:57). 
In fact, discipline during long hours of rehearsal stands behind either Wemba or Olomide's successful performance on the stage. In Olimide's orchestra, musicians are timeously aware about improvisational moves; therefore they plan to improvise and continuously rehearse on improving improvisational abilities during the concert (Moorman \& Miner, 1998). However, because fans assume that musical talents are spontaneous to either Olomide or Wemba, often they undermine efforts invested in terms of discipline during long hours of rehearsal that precedes a stunning performance. More than that, considering that Olomide's musicians have practice playing musical instruments for many years, they are able to instantly and simultaneously combine improvisational activities like playing, singing and dancing together (Moorman \& Miner, 1998).

In the course of time, they have developed listening and communication skills in specific areas such as politics, economy, musical and social life. Because musicians on the stage do not know their fans' feedback in advance, thus longer rehearsal period before the concert, better they will anticipate when responding to the fans.

As in Olomide's orchestra, good command of musical instruments is positively related to improvisational activities in team efforts. It is arguable that the lack of expertise among the team members will hinder the process of improvisation because it requires diverse set of skills in a team for a new product to be developed.

Perhaps the reason that research on IS improvisational for service branding has become somewhat self-sustaining is team work. This second dimension enables anyone to improvise, but like any game, if the players do not learn and obey the rules, no one will play with them (Halpern \& Close, 1994:34).

Although improvisational branding is unlikely, it still requires infrastructure, practice, expertise, and knowledge of the rules of collaboration. Team improvisation is not just a function of having the "right" expertise on the team. Rather, expertise must be coordinated within the team and its interdependencies should be managed effectively. The success of Koffi Olomide's improvisational performances depended on good team spirit of the entire orchestra because choreography performance depends on the interdependent work of other musicians and dancers (Sparks, 1994). When Olomide performs on the stage, every musician from the orchestra is responsible for the other; musicians look after one another and take the pressure off each other rather than increase it (Frost \& Yarrow, 1990). 
A successful performance of Olomide is a collaborative creation that cannot be understood by simply analysing every musician of the orchestra individually. Similarly, teamwork skills of team members in the organisation associated with quality improvisation include trust among members, a common goal, a shared responsibility, a common vocabulary, and the ability both to lead and to follow (Molnar, 2009).

Still on the list is that the collaboration needed for innovative team improvisation to brand an organisation is based on both cognitive and affective factors (Vera \& Crossan, 2005). It is agreeable that on the cognitive side, when improvisers share a collective mind, this fact enables better coordination when trying to come up with new processes of product development. Under pressure caused by processes to observe when developing a new product, effective teams are able to adapt and anticipate other members' information needs because of a shared understanding of the situation. Overcoming teamwork as an improvisational challenge creates transactive memory. Wegner (1987) defines transactive memory as the set of knowledge possessed by team members, coupled with an awareness of who knows what. It is an implicit part of the improvisational technique of rotational leadership, which means that musicians let different people take the lead depending on the needs of the situation on the stage. From the above, it is agreeable with Vera and Crossan (2005) that the greater the teamwork quality in terms of trust and cooperation in the organisation, the more positive the relationship between collective improvisation and innovation.

The third dimension of improvisational branding is team members' creative and spontaneous nature (Vera \& Crossan, 2005:209). For example if managers want team members to free-associate and embrace improvisational branding in a novel combination of optimisation, logistics and negotiation decision support tools, then they have to create an environment in which employees are not going to be punished for mistakes made when trying to develop that new products (Ghose, Hyland, Colins, Lau \& Ditsa, 2005). To ensure this environment, team members would rely on the principle of "agree, accept, and add" and to "make do" with whatever they have at hand (Weick, 1993). Halpern et al. argue that (1994: 35)

\section{“anything can happen in improvisation", however; "the only rule that can never be broken is the rule of agreement."}

Similarly, Frost and Yarrow (1990:110) argue that blocking team members' ideas is a denial of the possibility of encounter. Hence, the rule of agreement creates a context in which team members improvising are required to accept, support, and enhance the ideas expressed by others (Seham, 2001). The nascent improvisational literature indicates that blocking the ideas of 
other team members could be considered as form of aggression (Johnstone, 1979) because answering "no" to new ideas erases any possibility of new products to be developed (Vera \& Crossan, 2005:209).

A basic rule of improvisation in music performance on the stage requires musicians to be attentive to what is happening around them, meaning to be "present" and alert (Spolin 1963, Johnstone 1979). Being present at the spur moment embodies the fourth dimension of improvisation: real-time information and communication. When Koffi Olomide's choreographers perform a common move based on the song rhythms in the moment, insufficient attention and alertness to the rhythms coming from fellow choreographers leads to contradictory moves; creates conflict and frustration of both the performers and the audience. If one choreographer is planning ahead and thinking about the next direction to go, and is not paying attention to what is going on in the moment, he will miss opportunities for discovery.

Similarly, employees in the organisation with IS improvisational wherewithal need to learn to be attentive and alert to what is happening in the now of the firm. However, developing a system that highlights information (visibility and exchange), optimisation and negotiation requires infrastructures that provide improvisational teams with relevant real-time information in the context of market dynamics (Ghose, et. al., 2005).

Based on the practice of Congolese musicians and choreographers, the last dimension is that team members in an organisation cannot only learn from the principles of Olomide's choreographers and translate them to organisational business operations; they rather need to improve the effectiveness of their improvisational process through training that addresses the elements needed to improvise (Vera \& Crossan, 2005:209).

Given the above, one can argue that training not only has the capacity to increase employees' creativity, spontaneity, expertise, and teamwork quality; but also creates the context that supports improvisation, namely experimental culture, real-time information, communication, and transactive memory. Improvisational training needs to start by developing an understanding of what improvisation is and positioning it as a recommended choice. Even though effective deployment of optimisation technologies for branding has emerged, technology adoption model should be based on the firm's resource and its capabilities to rebrand (Vera \& Crossan, 2005:209). 


\section{THE RESOURCE-BASED VIEW MODEL FOR SERVICE BRANDING AND}

\section{INNOVATION}

The resource-based view (RBV) model was first introduced in 1959 in strategic management with the idea that a broader set of resources should be used in studying the firm (Penrose, 1959). In spite of the RBV's novelty, Penrose's idea did not gain momentum at the time. In the course of time, Wernerfelt (1984:172) introduced the concept that the firm's resources can be studied as its source of competitive advantage. Put differently, one can argue that the firm's assets, such as computer systems, skilled workers, brand name, the firm's improvisational knowledge, in-house knowledge of technology and customer relationships management, can lead to long-term performance of the organisation.

Further, Barney's (1991) work on the RBV indicates that brand names' competitive advantage (CA) occurs when a brand implements a system adding value in the process, creating strategy not simultaneously being implemented by other firms. Within that perspective, establishing the primacy in the novelty of systems implementation is important because it prevents competitive convergence of competing brands. It is arguable that a brand's resource should be valuable, rare, inimitable and non-substitutable (VRIN) in order to attract stakeholders (Barney, 1991:102).

The rationale of RBV is that the model examines technology adoption in the organisation based on the firm's resource and its capabilities to rebrand. One can argue that resources should be classified into tangible, intangible, and personnel-based resources. Drawing from Figure 1, the RBV model dwells in the junctions of the firm's capabilities include competencies such as employees' training, expertise, communication skills, and organisational culture of excellence in the combination of the resources at hand. Ray, Barney and Muhanna (2004) agree that according to the RBV model in Figure 3, assets to innovate namely computers, printers, scanners, Internet and connectivity, application server, database and storage and payment gateway, are major components in formulating an innovating e-commerce model aimed at re-branding an organisation. 


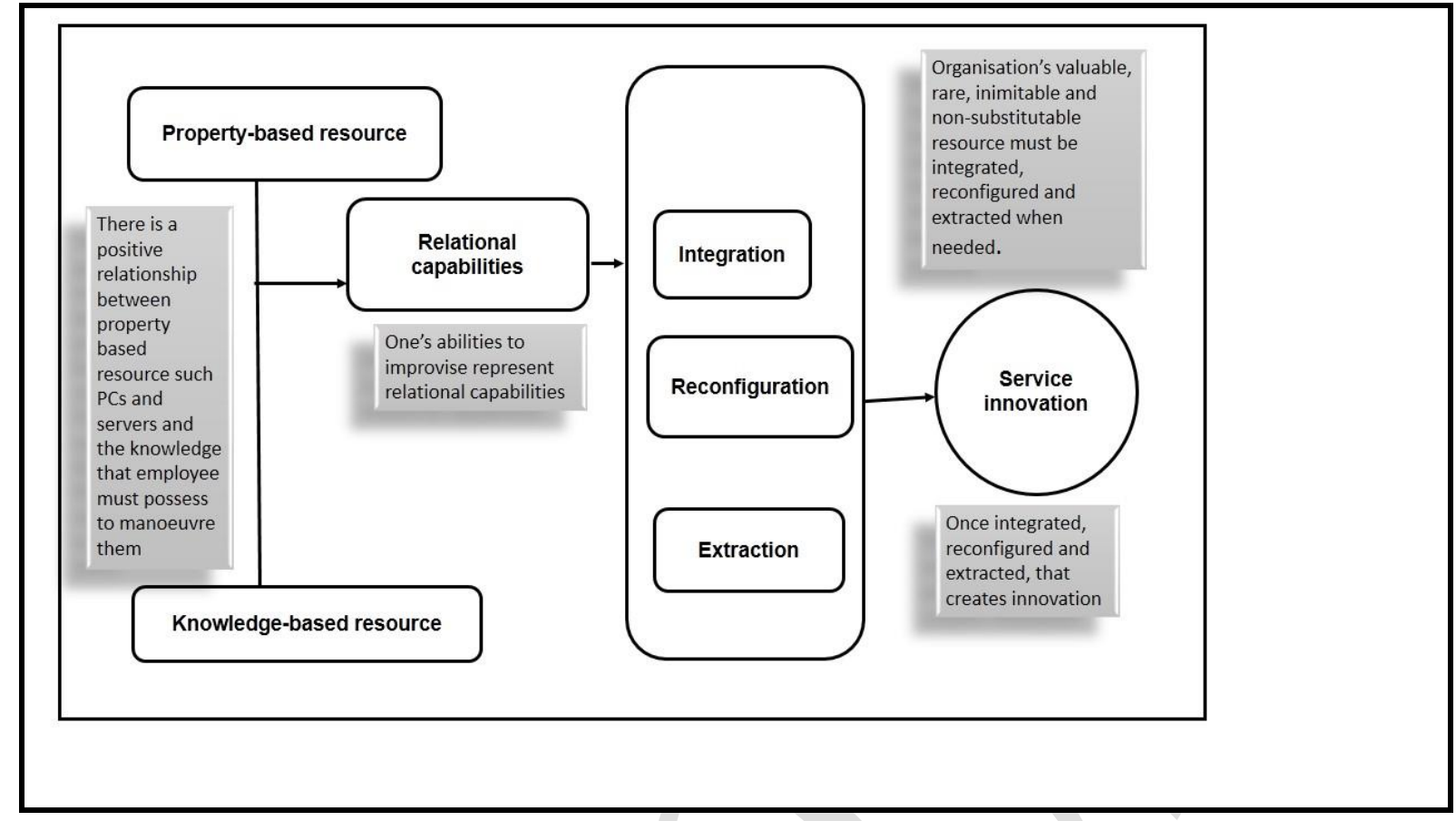

Figure 3. The Resource-Based View Model of E-Commerce

\section{ORTHODOXY OF IS IMPROVISATIONAL BRANDING}

Despite the growing usage of e-commerce in the business world, little evidence exists of academic research that proposes online business registration model (or Information Systems) for branding Government DTI in Congo (Ramnarain \& Govender, 2013). Nneka (2015:17) argues that this limitation could be due to inadequate expertise and creativity from the improviser to react swiftly in the process. In the digital branding context, improvisation has rather a positive connotation. Kokt and Koelane (2013: 3099) argue that owing to limited digital marketing resources, many organisations still use traditional marketing methods and this could be the case for most Government department in Congo-Brazzaville.

In the contrary, DTI South Africa invested in digital marketing resources, which included an advertisement database, a control database, and a communications network, in order to track much-needed entrepreneurs and boost the economy. Arguably, DTI South Africa's online business registration platform played crucial role in the country's competitive branding as investment destination (Doing Business, 2016). Furthermore, e-commerce improvisation created an opportunity for DTI South Africa to enforce Social Media Marketing (SMM). According to Wonjun and Chang Wan (2011), social media marketing campaigns in Facebook, Twitter and YouTube have the potentials to ignite corporate website traffic. Considering Congo's 105 
percent increase of national mobile cellular subscriptions (The World Bank, 2015), social media is more likely to contribute to an important shift from a traditional and institutional marketing to an emotive, personalised and digital one (Parson, Zeisser, \& Waitman, 1998:31).

A study sponsored by the city of Brazzaville revealed that there are only five marketing firms in Congo-Brazzaville (IZF, 2015). The study further concluded that both companies and DTI Congo should invest in digital marketing resources in order to promote nation branding, attract entrepreneurs and online consumers to share product experience in across their social networks (Illumine Marketing and Media, 2010). Increased Internet users rate from $1.9 \%$ in 2008 (The World Bank, 2008) to 6.6\% in 2015 (The World Bank, 2015) would be catalytic to the spread of electronic Word of Mouth (e-WoM) (Kichatov \& Mihajlovski, 2010). It can be argued that e-WoM would resonate with new product launch information, for instance in the Congo, because the link for such information would come from a trusted source, which could be DTI Congo's e-commerce Website. Drawing from the works of Kokt and Koelane (2013), it is arguable that e-commerce improvisation would enable organisations to migrate from paid media to earn media.

E-commerce improvisation within an organisation as argued by Shemi (2012), Garud and Karnøe (2003:277) is a "deliberate and substantive fusion of the Website design appeal and its functionality that would enable the institution to operate dynamically online $24 / 7$ '. Thus, the degree of e-commerce improvisation would depend on the substantive convergence between the organisation's Website planning, designing and implementation activities. Arguably, improvisation within business operations is positively related to the time gap between planning, designing, and implementing (Ferneley \& Bell, 2005). Considering that e-commerce improvisation is a creative process, spontaneity and extemporaneity are often overemphasised in the literature (Shemi, 2012). Drawing from the works of Dutta, Lanvinand Wunsch-Vincent (2014:7-8) and in view of the argument by Shemi (ibid.), effective e-commerce improvisation in an organisation would be guided by employees' intuition, and the real time nature of the action.

In tune to that, despite the fact that e-commerce improvisation might arise because of serendipitous events in the product-development value chain; it would likely be an intentional process involving consciousness of employees' action. In his work, Baker (2007:695) acknowledges that when employees act by improvisation the organisation's e-commerce Website planning, design, and implementation phases would converge. Such convergence would be an ongoing process to obtain a novel outcome (Johnson, 2005:364). However, the quality of outcomes would influence the organisation and vice-versa. 
In general, the novelty of the outcome would highlight the change in terms of service delivery mode without modifying the essence of what is being delivered (Johnson, ibid.). LéviStrauss (1966) argues that e-commerce improvisation in the organisation requires the use of resources at hand. In such extent, improvisation is akin to bricolage but still requests the fulfilment of its fundamental dimensions namely creativity (Tseng, Lee \& Chu, 2015:48-49), novelty (Baker \& Nelson, 2005), intuition (Tseng, Lee \& Chu, 2015:50), substantial convergence (Secchi, 2012), extemporaneous (Secchi, 2012) and absence of plan in the action (Tseng, Lee \& Chu, 2015:50). Similarly, Ciborra (2002) correlates scenarios in South Africa, USA and EU state members, where the merit of IS improvisation enabling service branding in public organisations.

\section{RESEARCH DESIGN AND METHODOLOGY}

The nature of research dictated a mixed method where quantitative and qualitative methodologies were used (Leedy, 1989:140). A sample size of $\mathrm{N}=260$ DTI Congo full-time employees from the total of 800 was used (Stat Trek, 2010). The targeted population comprised of 800 DTI Congo full-time employees who live in Brazzaville and Pointe-Noire, including males and females. For efficiency purposes, this study stratified DTI Congo full-time employees from the part-time and sub-contractors. According to Struwing and Stead (2001:122), stratified sampling technique enables the possibility to divide members of the population into homogeneous subgroups (strata) before sampling. The rationale was to improve the representativeness of the sample by reducing sampling error. The study used survey questionnaire to elicit information by requiring respondents to answer objective questions (Brace, 2004:9). However, to avoid conclusions from single transitory of data, a focus group meeting was used. Eight (8) DTI Congo full-time employees selected according to their level of IT awareness and position were invited for discussion to gain a broader understanding of the research problem (Brace, 2004:5). The outcome of the discussions was themes that informed the questionnaire and the sampling. Observation technique was also applied in the form of field work in Brazzaville and Pointe-Noire to experience what it is like when there is no other alternative to register a business but to follow the only lengthy and bureaucratic process of traditional business registration.

\section{FINDINGS}

The research questions were inspired by a literature study and discussions with industry practitioners and selected numbers of academics. The literature survey informed the 
underpinning theory and the discussions yielded useful information used to understand that there was indeed a lack of adequate understanding of online business system user's safety.

The survey questionnaire was developed from research overarching question: how does the DTI Congo-Brazzaville intend to improve business registration using e-commerce technology as a branding tool? The above stated question formed a basis for the focus group discussions as well.

The study used descriptive statistics, which refer to statistics that are used to describe relevant research data (Cherry, 2011:1). The rationale for descriptive statistics in this study thesis is to summarise the data collected in a clear and understandable manner (David, 2011). The research described single as well as associated variables. Single variables were associated with a theory-building concept and was analysed under the frequency section, whereas associated variables were associated with the theory-testing concept, which was analysed under the correlation section. However, the study surveyed 260 DT employees, asking each of them 55 questions. To avoid staggering with 14300 answers, the researcher used SPSS 22 data analysis involving the reproduction of data from unmanageable details to manageable summaries in order to reach meaningful conclusions (Babbie \& Mouton, 2009: 459).

The response rate was $61 \%$ because some respondents living in the city of Pointe-Noire were unable to return the questionnaire at work. However, the researcher attempted to trace their homes to collect the questionnaires. Unfortunately, that was not possible owing to the lack of proper street names and house numbers in the city of Pointe-Noire. Nevertheless, participating in this study represented national pride for the majority of respondents, who wish to create more awareness about Congo brand name as reliable investment destination.

\subsection{Respondents' Gender Representation}

The rationale for this information was to evaluate DTI Congo employees' IS improvisation mindsets by gender gap.

Table IV. Respondents' Gender Representation

\begin{tabular}{|cc|c|c|c|c|}
\hline & & Frequency & Percent & Valid Percent & Cumulative Percent \\
\hline \multirow{4}{*}{ Valid } & Male & 120 & 75.5 & 75.5 & 75.5 \\
& Female & 39 & 24.5 & 24.5 & 100.0 \\
& Total & 159 & 100.0 & 100.0 & \\
\hline
\end{tabular}

The results in Table IV reveal that among 159 respondents, $75 \%$ were male and $25 \%$ female. This shows that male respondents were dominant in this sample. Further scrutiny in this 
variable leads to a conclusion that in the absence of normative model, the intention to adopt an online business registration system for re-branding DTI Congo is largely based on male employees' favourable attitudes towards e-commerce. This attitude is in return influenced by a belief in tandem with the Resource-Based Theory (RBT) (Thamarai, Arasu \& Sivagnanasundaram, 2011:3). One can interpret that the belief has two components: belief about online business registration system adoption and belief in the self. Belief in online business registration system meant trusting that implementing online business registration system at the DTI Congo will enable local SMEs to gain a competitive advantage. Furthermore, belief in the self refers to male employees' capacity to improvise with resource at hand for successful online business registration aimed at branding Congo-Brazzaville.

\subsection{Information Systems Improvisation as Nation Branding Tool}

The rationale of this data was to evaluate how DTI Congo employees will combine their expertise and creativity to react swiftly in the product process. Another reason of this data was to correlate whether IS improvisation has the potentials to brand Congo-Brazzaville as business destination.

Table V. Information Systems Improvisation As Nation Branding Tool

\begin{tabular}{|cc|c|c|c|c|}
\hline & Frequency & Percent & Valid Percent & Cumulative Percent \\
\hline \multirow{4}{*}{ Valid } & Strongly agree & 79 & 49.7 & 49.7 & 49.7 \\
& Agree & 51 & 32.1 & 32.1 & 81.8 \\
& Disagree & 9 & 5.7 & 5.7 & 87.4 \\
& Strongly disagree & 20 & 12.6 & 12.6 & 100.0 \\
& Total & 159 & 100.0 & 100.0 & \\
\hline
\end{tabular}

$(\mathrm{N}=159)$

Table $\mathrm{V}$ above reflects that $49.7 \%$ of respondents strongly agreed; and $32.1 \%$ agreed; which totals $81.8 \%$ (49.7\% plus $32.1 \%$ ) who believe that IS improvisation at DTI Congo is possible. However, $5.7 \%$ disagreed and $12.6 \%$ strongly disagreed, which totals $18.3 \%(12.6 \%$ plus 5.7\%) who do not believe this. The marketing connotation of the above assertions imply that the e-commerce improvisation perceived will close the gaps between the growing usage of ecommerce in the business world and the current total vacuum of it at DTI Congo.

One can interpret that such limitation is because of expertise and creativity that will be required from improvisers to react swiftly in the business process. Shemi (2012) and Garud \& Karnøe (2003:277) share the opinion that online business improvisation at DTI Congo will be a "deliberate and substantive fusion of the Website design appeal and its functionality enabling the 
institution to operate dynamically online 24/7'" Thus, the degree of online business improvisation will depend on the substantive convergence between the organisation's Website planning, designing and implementation activities. Indeed, the more improvisational an activity in business process, the narrower the time gap between planning, designing, and implementing will be. Considering that online business improvisation is a creative process; spontaneity and extemporaneity will be required from DTI Congo employees.

Despite the fact that online business improvisation might arise because of serendipitous events in the product development value chain; it will likely be an intentional process involving consciousness of employees' action. Indeed, when employees act by improvisation, the organisation's online business Website planning, design, and implementation phases will converge.

Such convergence will be an ongoing process to obtain a novel outcome, namely the online business permit. The quality of that outcome will influence the organisation and viceversa. The novelty of the outcome will highlight the change in terms of service delivery mode without modifying the essence of what is being delivered. Lévi-Strauss (1966) argues that ebusiness improvisation in the organisation requires the use of resources at hand. In that context, improvisation is akin to bricolage but still requests the fulfilment of its fundamental dimensions such as creativity, novelty, intuition, substantial convergence, extemporaneous and absence of plan in the action. Similarly, Ciborra (2002) correlates scenarios applicable in Congo-Brazzaville where the merit of online business bricolage underscores the transformation of organisations from self-centred to market-driven, promoting lifelong learning.

\subsection{Focus Group Analysis}

The purpose of focus group discussions was to remove much of the subjectivity from summaries and to simplify the detection of trends, which answered research questions (List, 2005:1). As stated earlier, eight respondents were selected and invited for focus group discussions, which paved a vista for further academic discourse.

- What are the benefits you associate with normative model of online business registration system for DTI Congo?

During discussions around this question, respondents mentioned various benefits that will come with an online business registration system at DTI Congo. However, respondents mentioned that the model will a bench mark enabling the organisation to reach people worldwide in a way that even an expensive advertising media would not. They agreed on one point that 
online business registration will rebrand the country, increase DTI Congo's product and service information visibility.

Furthermore, respondents agreed also that online business registration at DTI Congo will connect entrepreneurs to CFBAP, the Ministry of SMEs, the Department of Labour (DoL), the Taxation Office, the High Court, the Congolese Chamber of Commerce (CCC), the National Centre of Statistics (NCS) and the Social Security Department (SSD). Such connections will be on $24 / 7$ basis and will enable electronic payments and VAT declarations, therefore reducing SMEs' operation costs, lead time and removing the incidence of occupational crime.

In addition, owing to the current trend of the "Knowledge-Based Economy" (KBE) where power shifts to consumers, participants emphasized that online business registration adoption will create an opportunity for DTI Congo workers to acquire a range of computer skills and to continuously adapt these skills. However, the aim of this question was to ascertain participants' basic understanding of the potential online business registration model before further scrutiny.

- How will DTI Congo's online business registration system transform the process?

During the focus group discussion, all eight participants agreed that an online business registration system will transform the business process at DTI Congo. However, the aim of this question was to ascertain respondents' understanding of the anticipated transformation from the current procedure. Respondents argued that in the brick-and-mortar business registration process, applicants have to follow every step from (1) receiving and forwarding application, (2) relevant directorate will be concerned with inputs evaluation, which would determine whether the output is satisfactory, or not, (3) outbound logistics, (4) marketing activities and (5) front office staff to help customers in collecting the outcomes.

Participants agreed that all the above-mentioned steps would be automated and integrated in an optimised online business registration system. Arguably, optimisation is a process of making a system as fully functional as possible (Ghose, et al., 2005). Thus, optimised online business registration system will shorten negotiations through e-logistics. As such, DTI Congo will achieve a conservative-relational competitive advantage, through the offering of a new product that delivers a superior customer-specific solution, which will be electronic submission of the application, electronic payment of the application fees and electronic delivery of the business permit. From the above, suggesting the actual normative model of online business registration became imperative.

Turkish Journal of Marketing Vol.:1 Issue:2 Year: 2016 pp. 163-194 


\subsection{Normative Model of Online Business Registration For Branding DTI Congo}

There was always a possibility of finding a solution to any problem that DTI Congo might encounter in its daily efforts to re-brand the country. Currently, the department faces a unique option enabling business registration: brick-and-mortar. Data analysis showed there was insufficient SMEs support in Congo-Brazzaville; yet the development of any country depends on economic diversification. There was a need for solutions to be found for local SMEs in order to improve the country's economic diversification.

The current research suggests this online business registration normative model, which is illustrated in Figure 4, for DTI Congo. This normative model is a hybrid model inspired from the resource-based view model $(\mathrm{RBV})$ for e-commerce innovation promoting service branding.

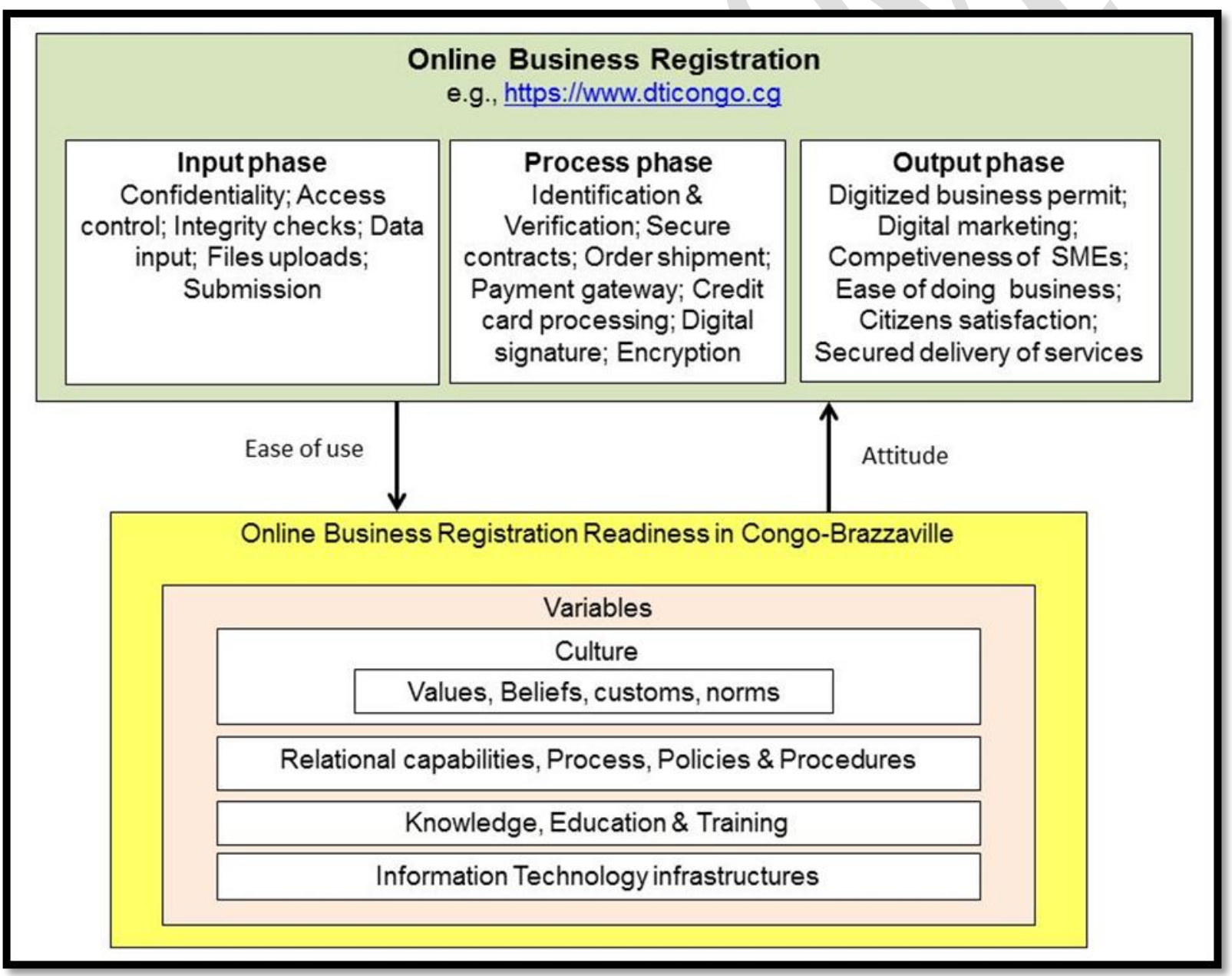

Figure 4. Proposed Online Business Registration Model For Branding DTI Congo 
This normative model is presented based on online business registration readiness at DTI Congo. Online business registration readiness refers to DTI Congo's propensity to embrace and use new technologies for SMEs support and improving the ease of doing business (Chih Chen \& Han Li, 2010).

\section{DISCUSSIONS}

Online business registration readiness requires working relationships between DTI Congo employees' attitudes towards the technology and their intentions to use it. On the other hand, the technology itself should be useful and easy to use. Attitudes refer to DTI Congo employees' positive or negative feelings about online business registration adoption, which in turn shapes ecommerce behavioural intention. However, attitudes, intentions, usefulness, and ease of use should be related to different variables representing market dynamics and demographics of Congolese end-users.

Culture as a variable includes Congolese values, norms, customs, and beliefs towards ecommerce. Various authors elaborated on the relationships between culture and e-commerce adoption. Al-Gaith, Sanzoni, \& Sandhu (2010:14) argue that consumers' culture is positively related to e-commerce Website security and privacy, which in return depends on trust and the level of education. Javalgi (2004:563) states that recently, researchers have attempted to examine Internet adoption by using Hofstede's five cultural dimensions, which include individualism, power distance, uncertainty avoidance, masculinity, and long-term orientation. Congolese attitudes towards e-commerce fit into some of Hofstede's five cultural dimensions of the Internet. Female entrepreneurs believe that Internet technology belongs to men, while some of their fellow men state that registering a business online in Brazzaville might create a feeling of uncertainty.

Another variable that has been considered in this normative model is dynamic service capabilities, which is borrowed from the RBV model. Considering that the RBV model is primarily a static theory which does not address how DTI Congo would integrate resources and capabilities to drive online business registration improvisation, the model links dynamic service capabilities with online security and safety of Congolese end-users. The rationale of the linkage is that since service firms such as DTI Congo operate in a constant changing business environment, it would arguably be better to go beyond the RBV model to explain the implementation of the innovation. 
DTI Congo's dynamic capabilities will include its ability to integrate, build, and reconfigure Internet security measures, which would reinforce the accessibility of the online business registration system. Such achievement would underline that the firm has addressed internal and external competencies and positioned its resources beyond the base set of valuables, rare, inimitable, and non-substitutable that the RBV model focuses on. Indeed, a secure online business registration service would enable DTI Congo's ability to adapt with market trends, innovate the process, adjust marketing strategies, and maintain competitive advantage while using the basic tenets of the RBV model. Further, this model is demarcated from the simple RBV model by emphasising on the critical role of managerial capabilities of DTI Congo managers to determine what value is and not what the employees interpret value to be.

Moreover, DTI Congo's ability to coordinate internal and external competencies underlines cooperation and interdependence of vertical and horizontal directorates. Collaboration between new business registration section, business modification section and business deregistration section will be enforced in this normative model. Thus, the relationships between stakeholders, namely the DTI Congo, the Ministry of SMEs, the CFBAP, the DoL, the taxation office, the high court, the NCS, the SSD, the trade unions and the IMF will be improved (Lee, Kang, \& Kim, 2007).

Relational capabilities are a variable associated with product process, policies, and procedures at DTI Congo. DTI Congo's conservative relational competitive advantage would depend on its ability to turn around resources at hand and capabilities into value creation process. Prahalad and Ramaswamy (2004) argue that the firm can create value by integrating customers in the product process. It is arguable that Congolese entrepreneurs want to get involved in an experience with DTI Congo in the product process, instead of just doing simple transactions. In the case of Congolese entrepreneurs' involvement, one believes that the increase of value cocreation in the product process at DTI Congo will provide unique and inimitable knowledge, which will become a new source of economic rent for the organisation.

Similarly, Ramaswamy and Gouillart (2010) emphasise the role of the firm's capabilities that allow it to engage in co-creation activities. Arguably, online business registration being an innovation represents a key factor of business networks between SMEs and the service provider. Considering that an online business registration system has potentials to increase the country's rating for ease of doing business, DTI Congo's ability to project the value creation in the product process might lead to funding opportunities for SMEs through partnership and sponsorship linkage. Lee, Lee, and Pennings (2001) argue that partnership linkage is a cooperative relationship between the partners that give and take their own resource and capabilities over long 
periods. However, sponsorship linkage is a one-sided relationship defined as technical, financial, and human support to a business without compensation.

Information technology infrastructures, knowledge, education and skills can be combined to generate dynamic integrative capability for DTI Congo. Mengue and Auh (2006) define integration as dynamic capability that firm level resources possess and are embedded in social interactions, firm-level system, and routines. Dynamic capability is an integrative capability comprising of all assets needed to improvise and to innovate. The former includes expertise, attitudes, training; the latter includes computer systems, trust, and creativity. The above blended form of resources and capabilities is positively related to transforming the entire business registration process in Congo-Brazzaville, because resource integration creates value. For example, the cable service industry used network infrastructure to only deliver cable television (TV) service to homes until the year 2000 (Kim et al., 2015). Using integrating capabilities, those same firms currently deliver Internet and telephone service, which provide more value to customers.

It is believed that under dynamic integrative capabilities, DTI Congo might progressively offer the combination of services such as online tax payment, online advertisement for SMEs and e-customs declaration effectively. Value creating activities at DTI Congo would require resource integration and relational capabilities so that the customer, as co-creator of value, integrates fewer resources as necessary (Michel, Brown \& Gallan, 2008).

Online business registration behaviour is the innovative service that would be offered at https://www.dticongo.cg. Gallouj and Weinstein (1997) argue that service innovation has two essential elements, namely enhanced technological characteristics, and extended competency. At DTI Congo, enhanced technological characteristics include tangible and intangible technical skills that will be used to improvise during product process. These characteristics will be embodied in e-commerce technologies, knowledge, experience, and values inside and outside the organisation. They are directly related to the primary activities of the value chain in the organisation, and simultaneously represent dominant designs that will lead to the standardisation of business registration marketplace and market space. Extended competencies refer to unique value-creating systems and DTI Congo employees' activities to be performed during online business registration improvisation and bricolage. The https://www.dticongo.cg which is DTI Congo's potential secure e-commerce Website, will cross the organisation's traditional 
boundaries and offer quality performance of innovative product gathering and processing data, while linking customers with all relevant directorates.

The input phase in this normative model represented the summary variables (confidentiality, access control, integrity, checks, data input and submission), which represented e- business registration steps. Therefore, the concept of input served as a powerful tool; since the elements included all the steps that users should follow in the systems to electronically register the business. However, the most important step would be to $\log$ on to the https://www.dticongo.cg. Thereafter, the user would register as customer in the Website with their private e-mail address, from which the system would prompt them to click the link to activate their registration with the https:/www.dticongo.cg. Once back again in the https://www.dticongo.cg, customers would $\log$ in with their activated credentials, namely user name and password. At this stage, online business registration starts by selecting new company option, where the newly to be registered business data will be typed in. After the data input stage, customers should be allowed to view, edit and save the data before electronic payment and submission to the DTI Congo.

The process phase includes identification and credit checks of the customers applying for company registration. At this stage, payment will be processed, during which secure verifications between DTI Congo's bank, credit card issuing organisation and customer's bank will exchange confirmatory data. During data exchange, encryption and digital signature will play crucial role for customer's data safety. Once confirmatory data match, order shipment will initialise to enable electronic product shipment to customer.

The output phase will deliver to the applicant and stakeholders much needed document and other information. The outcomes will include an online business permit delivery to the customer's private e-mail address and cellular phone notification about the outcomes. This first e-mail notification would be a blended form of DTI Congo resource combination and capabilities relating positively to the service innovation. Links under this first e-mail to customers should lead to social networks, potentially enabling digital marketing, which would be positively related to the SMEs SCA. Considering the short lead-time in the process, the ease of technology, and the perceived usefulness of the e-commerce Website, it is believed that highly satisfied customers will vehicle e-word of mouth about the innovation, which will improve Congo-Brazzaville's ease of doing business ratings.

However, in the context of this normative model, constant feedback will be important because relational capability is intangible; e-commerce technologies are constantly changing, 
therefore acquiring knowledge and information from external sources about the model becomes critical. Through dynamic interactions with customers and stakeholders, DTI Congo will be responsive to both evolutionary and revolutionary e-commerce technologies in the market. However, the next sections elaborate on the conclusions.

\section{CONCLUSION}

Protracted Congo brand name's inability to attract investors spells ruin. The research problem is that despite the potential role that can play IS improvisation in service branding in developing countries, despite wherewithal, Department of Trade and Industry (DTI) of CongoBrazzaville does not have a normative model for online business registration. Such insufficiency stunts Congo's brand name as investment destination. Thus, the study uses the lens of improvisational knowledge and Resource-Based View model to explore IS improvisational model as a means to rebrand services at the DTI Congo-Brazzaville. Therefore, the main study outcome is to propose normative model of online business registration for service branding. However, this paper has three major contributions namely theoretical, methodological and practical contribution.

Theoretically, this study will advance conceptualisation of IS improvisation and bricolage and brand personality theories for public organisation in many ways. Firstly, the study extends previous research by examining the implications of creating an online business registration model for re-branding government department in developing country. Secondly, the research highlights the relationships between IS improvisation and branding theories in public organisations.

Thirdly, there is a recognition of global warming theory in the establishment of online improvisation theory in public organisation. Current climate change blamed for most of natural disasters such as tsunami, floods sweeping towns and inhabitants, volcanic eruptions spreading ashes in the air and blocking air traffic for weeks and pollution. The study argues that online business registration adoption in public organisation is an evidence of environmentally friendly practices; which support green value chain initiatives. Online business registration system has the potential to replace paperwork by paperless in the business process. Thus, replacing traditional business registration service by online one, at DTI Congo reflects a true theoretical contribution of this study to brand personality theory and sustainability theory in a way far more impactful than recycling papers in the bin. 
Fourthly, current offline business registration at DTI Congo undermines business ethics. The CFBAP, which is DTI Congo legitimate agency to register businesses issues business permit applicant four different numbers for one registered business: registration number, accounting registration number, commerce registry number and real estate number. The plethora of numbers increases the incidence of unethical business practices, poverty, opportunistic behaviour, corruption, occupational crime and heavy bureaucracy, which erode the department's efficiency, accountability and agility. Arguably, successful IS improvisation theory at DTI Congo advances green value chain theory in a sense that IS improvisation will introduce paperless process, protect ecological structure of the environment, enforce corporate social responsibility theory and lean organisation theory.

Fifthly, successful IS improvisation theory at DTI Congo will contribute to nation branding theory. The country is known for being at the bottom of the pile when it comes to the ease of doing business ratings. These findings are cause for concern especially as there is growing awareness that Congolese business' inability to compete in a fiercely competitive international economy spells ruin. Online business registration system will boost the DTI Congo's profile; re-brand the department, improve the country's ranking in terms of ease of conducting business and significantly reveal value bundling of well-established IS infrastructure in a government department and its capacity to utilise such infrastructure as competitive nation branding; and label the country as investment destination in Central Africa.

Methodologically, this study was based on data collected through participant observation, focus-group meeting, survey questionnaire, existing academic literature and analysis of archival and policy documents of business registration in Congo-Brazzaville. The study is methodologically innovative because it was conducted in English speaking country while the survey questionnaire was distributed in French speaking country. The innovative point lies on the fact that respondents' first language is French, thus, English and French back-to-back translation was utilised for better understanding of the questionnaire. However, ethical considerations such as voluntary participation of respondents, freedom in the process, respondents' safety, security, anonymity, confidentiality and secure storage and transport of data from Congo-Brazzaville to South Africa were highly observed.

Practically, results of this study can help to implement normative marketing model of online business registration re-branding DTI Congo. Considering that online business registration has the potentials to permeate SMEs' value chain, the application of this research findings can transform SMEs' performance, and improve the functional relationship between inbound and outbound logistics and increase sales and marketing activities of Congolese SMEs. 
This research output has the potential to ignite the creation of Congolese Business Intelligence Centre (BIC), which does not exist yet. The BIC will be a learning curve for entrepreneurs and enable local SMEs to accumulate knowledge from foreign markets and promote their expansion. Indeed, learning business practices from other businesses outside national boundaries would give local entrepreneurs experience and result in a more differentiated view of foreign markets. Practically, the study itself is very informative for DTI Congo because current business sector re-structuring efforts include recent Congo-Brazzaville government critics for introducing drastic measures targeting foreign-owned businesses. The study argues that simply introducing drastic measures targeting foreign-owned business do not lead to competitive advantage of local SMEs. Instead, that leads to competitive convergence amongst local businesses. Rather, DTI Congo should re-brand itself by creating corporate personal brand identity when dealing with local entrepreneurs to offer local SMEs much needed support including the adoption of an online business registration system. The study practically reveals available e-commerce tools that DTI Congo can potentially purchase, to re-brand and position its business process for quality service delivery to target segments.

This study has some limitations. The study focused on proposing a normative model for

online business registration at DTI Congo-Brazzaville only and its relative benefits to the organisation. Hence, does not examine online business registration service users' benefits. Arguably, this research does not recommend any specific e-commerce technology to DTI Congo, but as an institution, DTI Congo should evaluate the pros and cons of different e-commerce technologies, and then decide on the most appropriate technology for its potential e-commerce website, which should be managed at Brazzaville's head office. It is the first time that such a study has been conducted in South Africa, which proposes online business registration model aimed at re-branding the government department in Congo-Brazzaville in order to make Congolese brands more competitive.

Given Whetten's framework for the assessment of any academic research, the conclusion of this research study both answers the study's questions and generates new ones (Whetten, 1989). The study was considered to be a social constructed one and therefore assumed adopting ontologically subjective and objective position. The findings display some shortcomings and these limitations should be recognised when interpreting the findings, while also recognising opportunities that they present for further research in the areas of legislation reforms and nation branding.

Turkish Journal of Marketing Vol::1 Issue:2 Year: 2016 pp. 163-194 
One of the challenges of branding a nation as investment destination is the need to separate politics and business in the country. The Act $\mathrm{N}^{\circ} 36-2011$ of 29 December 2011, the section 8 of the Act $N^{\circ}$ 36-2011 of December 292011 fixing business registration fees lower for nationals and higher for foreigners and are politically motivated. However, no research has been conducted to establish the impact of politically motivated business registration fees policy on nation branding.

Currently, nation brands are equated to corporate brands because nations represent umbrella brands where sub-brands such as tourism, investment, export, transport and manufacturing can grow. In Congo-Brazzaville, there is a research gap in terms of a model that explains how Congo as brand can be integrated within sub-brands in order to build sustainable brand equity for the nation brand and its affiliate brands. 


\section{REFERENCES}

Al-Gaith, W., Sanzoni, L. \& Sandhu, K. (2010), "Factors influencing the adoption and usage of online services in Saoudi Arabia", Electronic Journal of Information Systems, Vol. 40 No. 1, pp. 1-32.

Amabile, T. M. (1996). Creativity in Context. Westview Press, Boulder, CO.

Baker, T. and Nelson, R. E. (2005), "Creating something from nothing: Resource construction through entrepreneurial bricolage", Administrative Science Quarterly, Vol. 50 No. 3, pp. 329-366.

Brace, I. (2004), Questionnaire Design: How to plan, structure and write survey material for effective market research. London: Kogan.

Babbie, E. \& Mouton, J. (2009), The practice of social research. Cape Town: Oxford University Press.

Baker, T. (2007), "Resources in play: Bricolage in the Toy Store(y)", Journal of Business Venturing, Vol. 22 No. 1, pp. $694-711$.

Baker, T., Miner, A.S. \& Eesley, D.T. (2003), "Improvising firms: bricolage, account giving and improvisational competencies in the founding process", Research Policy, Vol. 32 No. 1, pp. 255-276.

Barney, J. (1991). "Firm resources and sustained competitive advantage", Journal of Management, Vol. 17 No. 1 , pp. 99-120.

Cherry, K. (2011). What are descriptive statistics? Available at:

http://psychology.about.com/od/dindex/g/descstats.htm[Accessed on 06/02/2011].

Ciborra, C. (1999). "Notes on Improvisations and Time in Organizations", Accounting, Management and Information Technologies Vol. 9 No. 1, pp. 77-94.

Chih Chen, S. \& Han Li, S. (2010). "Consumer adoption of e-service: Integrating technology readiness with the theory of planned behaviour", A frican Journal of Business Management, Vol. 4 No. 16, pp. 3556-3563.

Congo Vision. (2015), Les plus belles voix musicales des deux Congo réunies dans Terre sacrée. Available at: http://www.congovision.com/ambongo2.html [Accessed on 20/05/2015].

Cumming, D. (2011), "The differential impact of the Internet on spurring regional entrepreneurship", Strategic Direction, Vol. 27 No. 6.

Chambre de Commerce, d'Agriculture, d'Industry et de Métier de Brazzaville. (2014), Centre de Formalités des Entreprises (CFE). Available at: http://www.cciambrazza.co m/index.php?contexte=cfe [Accessed on 18/12/2014].

Chan, B. \& Al-Hawamdeh, S. (2002), "The development of e-commerce in Singapore”, Business Process Management Journal, Vol. 8 No. 3, pp. 278-288.

Chelariu, C. Johnston, W.J. \& Young, L. (2002), "Learning to improvise, improvising to learn: a process of responding to complex environment” Journal of Business research, Vol. 55 No. 2, pp. 141-147.

Danzig, M. (2002), “By design: The Blue light brand story”, Design Management Journal, Vol. 13 No. 1, pp. 26-32. 
Doing Business. (2015), Ease of Doing Business in the Congo Republic. Available at: http://www.doingbusines s.org/data/exploreeconomies/congo-rep [Accessed on 20/05/2015].

Doing Business. (2016), South Africa. Available at: http://www.doingbusiness.org/data/exploreeconomies/southafrica/\#close [Acces sed on 19/04/2016].

Dybå, T. (2000), “Improvisation in Small Software Organizations”. Software, IEEE, Vol. 17, pp. 82-87.

Dutta, S., Lanvin, B. \& Wunsch-Vincent, S. Ed. (2014), The Global Innovation Index 2014: The Human Factor in Innovation. Confederation of Indian Industry.

David, M. (2011), Descriptive statistics. Available at:

http://davidmlane.com/hyperstat/A28521.html [Accessed on 07/02/2011].

Durie, B. (2001), E-Business essentials. Oxford: How to books.

Ferneley, E. and Bell, F. (2006), "Using bricolage to integrate business and information technology innovation in SMEs", Technovation, Vol. 26 No. 2, pp. 232-241.

Faraj, S. \& Sproull, L. (2000), “Coordinating expertise in software development teams”, Management Science, Vol. 46, pp. $1554-1568$.

Garud, R. \& Karnøe, P. (2003). "Bricolage versus breakthrough: distributed and embedded agency in technology entrepreneurship", Res earch Policy, Vol. 32, pp. 277-300.

Ghose, A.K., Hyland, P.N., Colins, A., Lau, S.K. \& Ditsa, G. (2005), “Designing a regional e-logistics portal. 16th Australian Conference Information Available at: https://www.academia.edu/28505560/Designing_a_regional_e-logistics_portal [Accessed on 02/02/2017].

Gallouj, F. \& Weinstein, O. (1997), “Innovation in services”, Research Policy, Vol. 26 No. 4, pp. 537-556.

Frost, A., R. Yarrow. (1990), Improvisation in Drama. St. Martin's Press, New York.

Halpern, C., D. Close, K. Johnson.(1994), Truth in Comedy. Meriwether Publishing Ltd., Colorado Springs, CO.

IZF. (2015), Agence Publicitaire locales. Available at: http://www.izf.net/content/agence-publicitaires-localescongo-0 [Accessed on 20/05/2015].

Illumine Marketing and Media. (2010), Available at: http://www.slideshare.com [Accessed on 10/05/2015].

Javalgi, R.G. (2004). The Export of e-services in the age of technology transformation: challenges and implications for international service providers. Journal of Services Marketing, Vol. 18 No. 7, pp. 560-573.

Johnson, J.L. (2005), Organisational capabilities in e-commerce: An empirical investigation of e-brokerage service providers. Journal of the Academy of Marketing Science, Vol. 33 No. 3, pp. 360-375.

Johnstone, K. (1979), Impro: Improvisation and the Theatre. Hazell Watson:Bucks, England.

Kotler, P. (2003), Marketing Management. 11th Ed. Upper Saddle River, NJ: Prentice Hall.

Kichatov, V. \& Mihajlovski, N. (2010), Marketers cannot overlook this phenomenon of social media as it is one of the easiest means for generating communication with the consumer. Available at: http://www.marketingcharts.com [Accessed on 02/09/2014]. 
Kokt, D. \& Koelane, T. (2013), "Reflecting on Information and Communication Technology (ICT) in marketing from a marketer's and student perspective", African Journal of Marketing Management, Vol. 7 No. 3, pp. 30983108 .

Kim, M. \& Song, J. \& Triche, J. (2015), Toward an integrated framework for innovation in service: A resourcebased view and dynamic capabilities approach. Information Systems Front, Vol. 17, pp. 533-546.

Lee, C., Lee, K., \& Pennings, J. M. (2001), “Internal capabilities, external networks, and performance: a study on technology based ventures", Strategic Management Journal, Vol. 22 No. 6-7, pp. 615-640.

List, D. (2005), Know your audience. Available at:

http://www.audiencedialogue.net/kya16a.html [Accessed on 07/02/2011].

Leedy, P. (1985), Practical research: planning and design. New York. Macmillan

Publishing Company.

Lévi-Strauss, C. (1966), The savage mind. Chicago: University of Chicago Press.

Lee, K. C., Kang, I., \& Kim, J. S. (2007), "Exploring the user interface of negotiation support systems from the user acceptance perspective”. Computers in Human Behaviour, Vol. 23, pp. 220-239.

Ministère du Commerce. (2014), Presentation. Available at http://www.ministerecommerce.cg/le_ministere/presentation_du_ministere.html [18/12/2014].

Molnar, W.A. (2009), Information system development in a process management environment: the dynamics of improvisation and bricolage during embedded software design. Unpublished $\mathrm{PhD}$ thesis: University of Warwick.

Moorman, C., \& Miner, A. (1998), The Convergence of Planning and Execution: Improvisation in New Product Development. Journal of Marketing, Vol. 62 No. 3, pp. 1-20.

Mengue, B. \& Auh, S. (2005), "Balancing exploration and exploitation: The moderating role of competitive intensity”, Journal of Business Research, Vol. 58 No. 12, pp. 1652-1661.

Michel, S., Brown, S. W., \& Gallan, A. S. (2008), "Service-logic innovations: how to innovate customers, not products",California Management Review, Vol. 50 No. 3, pp. 54-66.

Nneka, A.A. (2015), "Extent of application of marketing mix strategy by Small and Micro Scale Enterprises in Osun State, Nigeria”, African Journal of Marketing Management, Vol. 7 No. 2, pp. 16-19.

Nikoloyuk, G.M. Marche, S. McNiven, J. (2005), "E-commerce impact on Canadian public sector audit practice”, International Journal of Public Sector Management, Vol. 18 No. 1, pp. 83-95.

52. PMC Cabinet. (2006), Étude diagnostique du Guichet unique et des barrières à l'investissement privé au Congo. PMC Unpublished research report.

Papathanassiou, E. Arkoumani, B. \& Kardaras, D. (2003), "Management context and impact of e-commerce in the Greek food industries”, Logistics Information Management, Vol. 16 No. 2, pp. 134 -144. 
Prahalad, C. K., and Ramaswamy, V. (2004), The future of competition: Co-creating unique value with customers. Harvard Business Press.

Penrose, E. G. (1959), The theory of the growth of the firm. New York: Wiley.

Parson, A., Zeisser, M. \& Waitman, R. (1998), "Organising today for the digital marketing tomorrow", Journal of Interactive Marketing, Vol. 12 No. 1, pp. 31-46.

Radio France International. (2015), Invité Afrique. Le musicien congolais Ray Lema. Available at: http://www.rfi.fr/emis sion/20140309-ray-lema-rca-concert-solidaire-centrafrique-paris-

/\#./?\&_suid=143238994692307964816652169202 [Accessed on 20/05/2015].

Ray, G., Barney, J. B., \& Muhanna, W. A. (2004), “Capabilities, business processes, and competitive advantage: choosing the dependent variable in empirical tests of the resource based view", Strategic Management Journal, Vol. 25 No. 1, pp. 23-37.

Ramnarain, Y. \& Govender, K. (2013), "Social media browsing and Consumer Behaviour: Exploring the youth market”, African Journal of Business Management, Vol. 7 No. 8, pp. 1885-1893.

Sparks, J. (1994), "Machiavellianism and personal success in marketing: The Moderating role of latitude for improvisation", Journal of the Academy of Marketing Science, Vol. 22 No. 4, pp. 393-400.

Simpson, M. \& Docherty, A.J. (2004), "E-commerce adoption support and advice for UK SMEs", Journal of Small Business and Enterprise Development, Vol. 11 No. 3, pp. 315-328.

Ramaswamy, V., \& Gouillart, F. (2010), The power of co-creation. New York: Free Press.

Shemi, A. P. (2012), Factors affecting e-commerce adoption by SMEs: An interpretative study of Botswana. Salford Business School: Unpublished PhD thesis.

Secchi, E. (2012), Essays on Service Improvisation Competence: Empirical Evidence from the Hospitality Industry. Graduate School of Clemson University: Unpublished $\mathrm{PhD}$ thesis.

Seham, A. (2001), Whose Improv is it Anyway? Jackson, Mis sis sippi: University Press

Spolin, V. (1963), Improvisation for the theatre. Evanston, Illinois: North-western University Press.

Stat Trek. (2010), Teach yourself Statistics: Random number table. Available at:

http://stattrek.com/Tables/Random.aspx [Accessed on 02/10/2010].

Struwing, F.W. \& Stead, G.B. (2001), Planning, Designing and Reporting Research. Cape Town: Pearson.

The World Bank. (2008), The Republic of Congo at a glance. Available at:http://www.worldbank.org [Accessed on 12/02/2009].

Thomson, S.H. \& Pian, Y. (2003), “A contingency perspective on Internet adoption and competitive advantage”, European Journal of Information System, Vol. 12, pp. 78-92.

Tseng, H.L., Lee, Y-C., \& Chu, P. (2015), "Improvisational capabilities in e-commerce adoption: A Multiyear comparison”, Journal of Global Information Technology Management, Vol. 18 No. 1, pp. 48-66. 
Thamarai S.N., Arasu, S. \& Sivagnanasundaram, M. (2011), "Role of existing channels on customer adoption of new channels: a case of ATM and internet banking”, The Electronic Journal on Information Systems in Developing Countries, Vol. 45 No. 1, pp. 1-15.

The World Bank. (2015), Mobile cellular subscriptions (per 100 people). Available at: http://data.worldbank.org/indicator/IT.CEL.SETS.P2 [Accessed on 20/05/2015].

Vukasovic, T. (2013), "Building successful brand by using social networking media", Journal of Media and Communication Studies, Vol. 5 No. 6, pp. 56-63.

Vera, D., M. \&. Crossan, M. (2005), “Improvisation and innovative performance in teams”, Organization Science, Vol. 16 No. 3, pp. 203-224.

Wegner, D.W. (1987), Transactive memory: A contemporary analysis.New York: Springer.

Weick, K. (1993), “The collapse of sensemaking in organizations: The Mann Gulch disaster", Administrative Science, Vol. 38 No. 4 , pp. 628-652.

Wernerfelt, B. (1984), “A resource based view of the firm”, Strategic Management Journal, Vol. 5 No. 2, pp. 171180 .

Wetten, D. (1989), "What constitutes a Theoretical contribution?", Academy of Management Review, Vol. 14 No. 4, pp. 490-495.

Wonjun, C. \& Chang Wan, W. (2011), "The effects of hosting an international sport events on a host country: The 2008 summer Olympic Games”, International Journal of Sport Marketing \& Sponsor, Vol. 12 No. 4.

Yétéla, M. (2012). Presentation of CFBAP. 